\title{
BIOSORPTION OF CU(II) IONS FROM INDUSTRIAL EFFLUENTS BY RICE HUSK: EXPERIMENT, STATISTICAL, AND ANN MODELING
}

\author{
Nirjhar BAR ${ }^{1,2 *}$, Tania MITRA ${ }^{2}$, Sudip Kumar DAS ${ }^{2}$ \\ 1,2St. James' School, 165, A.J.C. Bose Road, 700014 Kolkata, West Bengal, India \\ ${ }^{2}$ Chemical Engineering Department, University of Calcutta, 92, A. P. C. Road, 700009 Kolkata, \\ West Bengal, India
}

Received 29 October 2020; accepted 10 December 2020

\author{
Highlights \\ Removal of $\mathrm{Cu}(\mathrm{II})$ from wastewater is reported. \\ Rice husk is used as adsorbent. \\ Artificial neural network has predicted the percentage removal better than MLR.
}

\begin{abstract}
Heavy metal removal from wastewater is a significant research area and recommends sustainable development. The heavy metals cause harmful health effects, increase environmental toxicity. Adsorption is a very effective method for heavy metal removal. A fixed bed for $\mathrm{Cu}(\mathrm{II})$ removal using rice hush, an agricultural waste, is reported in this paper. The study was carried out to determine the breakthrough curves with varying operating variables like influent concentration $(10-30 \mathrm{mg} / \mathrm{L})$, flow rate $(10-40 \mathrm{ml} / \mathrm{min})$, and bed height $(4-10 \mathrm{~cm})$ at $\mathrm{pH}$. The variation of the process variables like influent concentration, flow rate, and bed height were investigated. The experimental data shows that adsorption capacity increases with the rise of influent concentration. The maximum value of adsorption capacity is $10.93 \mathrm{mg} / \mathrm{g}$ at a flow rate of $10 \mathrm{ml} / \mathrm{min}$, bed height $4 \mathrm{~cm}$, and influent concentration $30 \mathrm{mg} / \mathrm{L}$. The applicability of the MLR and ANN modeling has also been successfully carried out. ANN has better predictability than MLR. The findings revealed that rice husk could be used to treat copper-containing industrial effluents.
\end{abstract}

Keywords: wastewater management, water pollution, environmental sustainability.

\section{Introduction}

Wastewater containing toxic, hazardous heavy metal ions discharged by several industries is a global problem today (Kumar et al., 2019). Wastewater management is essential for reducing water pollution. Environmental sustainability is dependent on it. This water stream associated with metal ions is mixed with freshwater bodies and makes the new system polluted. These are like $\mathrm{Pb}(\mathrm{II}), \mathrm{Cu}(\mathrm{II}), \mathrm{Cr}(\mathrm{VI})$, $\mathrm{Ni}(\mathrm{II}), \mathrm{Zn}(\mathrm{II})$, can entered into the functional parts of the living beings through the water bodies and damage these vital parts of the body. Like all other metal ions, $\mathrm{Cu}(\mathrm{II})$ ions are also necessary for human health trace amounts. Still, an excessive amount can damage vital organs such as the nervous system, digestive system, excretory system, etc. (Mitra \& Das, 2020). On the other hand, water is also required for living organisms. So, it is required to make the water-bodies metal ions free within the permissible limit. Several technologies are present to treat these wastewaters like membrane separation, ion exchange, precipitation, coagulation, adsorption using the activated carbon, and adsorption using bio-sorbent (Aydin et al., 2008). Several industries, like the battery electroplating industries, manufacturing industries, smelting and metal finishing industries, etc. (Tumin et al., 2008) discharged $\mathrm{Cu}(\mathrm{II})$ ion-containing wastewater in rural areas. According to the Govt. norms, most of these industries in rural areas are small and medium-sized and cannot treat the wastewater due to financial constraints. Hence, the development of a low-cost economic process is necessary. Other processes like membrane separation, ion exchange are not economical, and precipitation, coagulation (Gayathri et al., 2011) are not efficient for industrial-scale treatment. World Health Organization (1993), Environmental Protection

*Corresponding author. E-mail: nirjhar@hotmail.com 
Agency (1990), Bureau of Indian standards (1991) recommended the $\mathrm{Cu}(\mathrm{II})$ ions discharging limit to the water body(s). These are $2.0,3.0,0.25 \mathrm{mg} . \mathrm{L}^{-1}$ respectively. Activated carbon as adsorbent is a very efficient process, and activated carbon is too much effective adsorbent but not recommended for small and medium-sized industrial treatment due to its high cost. So, searching for lowcost, economical, easily-available adsorbents is the basic need for the current situation. Hyacinth root, blackberry leaves, guava leaves, rice husk, rice bran, coconut shell, neem leaves, etc., are available locally and used as adsorbent without any treatment or modification. So, the preparation cost of these adsorbents is negligible. Rice husk is one such green natural adsorbent used to treat $\mathrm{Cu}(\mathrm{II})$ ions in the column mode without any modification or treatment.

Data modeling has been performed using multiple linear regression (MLR) (Nag et al., 2020; Das et al., 2020; Mandal et al., 2020) and Artificial Neural Network (ANN) (Kumar et al., 2019; Mitra et al., 2014; Das et al., 2015; Maiti et al., 2018) with success for the last few years. Proper analysis of data produces beneficial results if interpreted correctly using a statistically approved process like MLR. MLR can show the relationship between the independent and dependent variables. When it is extremely complicated to get any statistical/mathematical relationship between the variables, then ANN is the tool that has successfully produced the desired results.

Physical characterization was made to identify rice husk's physical properties, and the experiment was done to check the suitability of rice husk to remove $\mathrm{Cu}$ (II) ions. Experimental data was used to predict the Empirical/semi-empirical model. Artificial neural network prediction was made to compare with the experimental data to check the rice husk capacity, and MLR analysis was also made in the study.

\section{Materials and method}

\subsection{Adsorbent preparation}

Rice husk is used as an adsorbent and collected from Bandel, Hooghly. It is washed with and dried under the sun for a few days and finally dried in the oven for 7-8 hrs. at $60{ }^{\circ} \mathrm{C}$. Dried adsorbents are crushed and sieved for the particle size of about 290 to $350 \mu \mathrm{m}$ and then kept within a desiccator.

\section{2. $\mathrm{Cu}(\mathrm{II})$ ion solution preparation and analysis}

The $\mathrm{Cu}(\mathrm{II})$ ions stock solution of $1000 \mathrm{mg} / \mathrm{L}$ is made by dissolving $3.93 \mathrm{gm}$ of copper sulfate pentahydrate in $10^{3} \mathrm{ml}$ of distilled water and diluted for the required standard solution. Influent and effluent $\mathrm{Cu}(\mathrm{II})$ ion concentration is measured in an Atomic absorption spectrophotometer (Model: AA 240 VARIAN, Australia). Analytical grade from E. Merck Ltd., Mumbai, India are used.

\subsection{Characterization of rice husk}

BET (Novawin 1000, Quantachrome, USA) was used to determine rice husk BET's surface area. The $\mathrm{pH}_{\mathrm{PZC}}$ of rice husk was measured by the solid addition method. The surface morphology of rice husk was obtained from SEM (Scanning Electron Microscope) (EVO-Q400++, from ZEISS, Germany) image. The rice husk has a surface area of $0.54 \mathrm{~m}^{2} / \mathrm{g}$, and its Point of zero charge $\left(\mathrm{pH}_{\mathrm{PZC}}\right)$ is 6.05 . Figure 1 shows the SEM image of the rice husk.

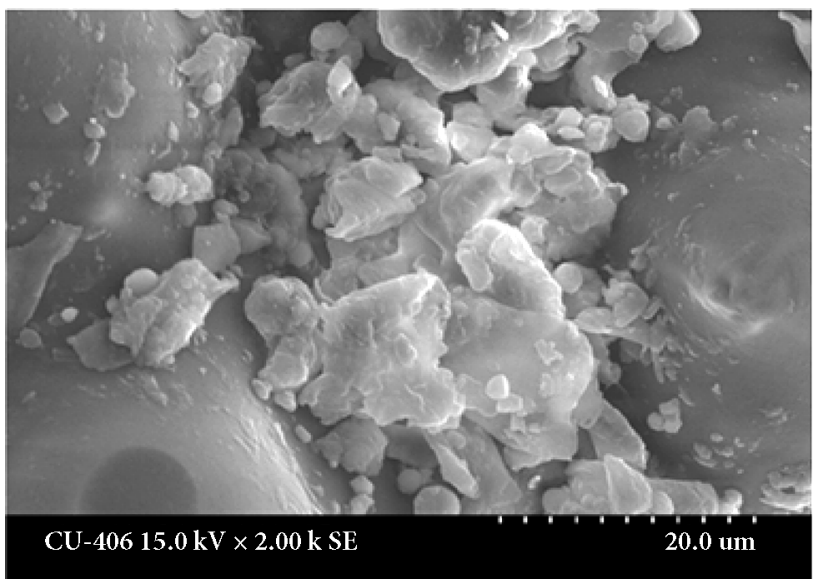

Figure 1. SEM image of the rice husk

\subsection{Column process}

The columns are made of glass (ID $1.8 \mathrm{~cm}$ and length $50 \mathrm{~cm}$ ), The $\mathrm{Cu}(\mathrm{II})$ ion solution is introduced from the top of the column by peristaltic pump. The adsorbent was then placed in the column at the desired height, and water was added to settle down the adsorbent. A metal sieve plate and glass wool is placed just above to provide the mechanical support, and adsorbent loss. The solution was collected from the column bottom, and the concentration of the effluent solution was measured in AAS. Figure 2 is the schematic diagram representing the experimentation of the continuous process.

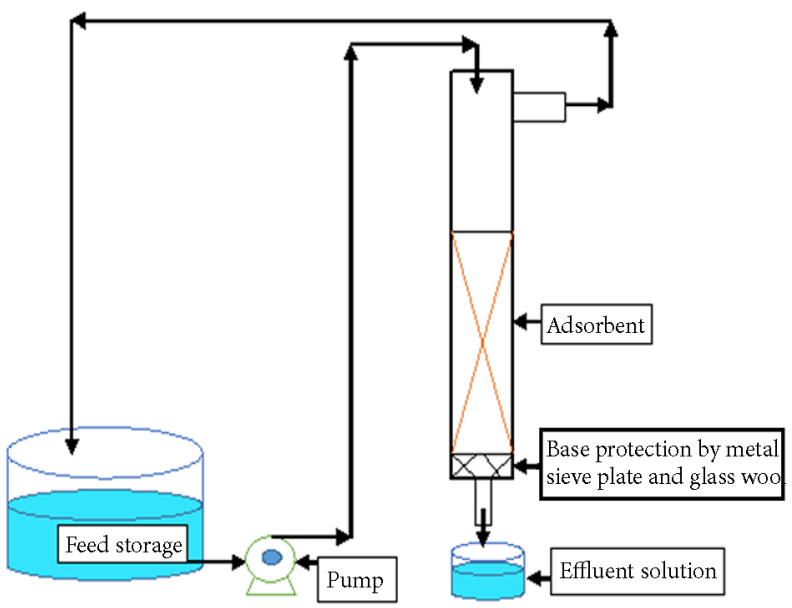

Figure 2. Experimental set-up (schematic presentation) 


\section{Results and discussion}

\subsection{Variation of process parameters}

Batch experiment was done at different $\mathrm{pH}(2-8)$, and $\mathrm{pH}$ 6 was found to be the optimum (Singha \& Das, 2013). At lower $\mathrm{pH}$, the $\mathrm{H}_{3} \mathrm{O}^{+}$ion concentration is more at and around the adsorbent and the diffusion of the $\mathrm{Cu}$ (II) ion is difficult, hence the $\mathrm{Cu}(\mathrm{II})$ ions removal is less. Also, at $\mathrm{pH}$ higher than 6, precipitation of $\mathrm{Cu}(\mathrm{OH})_{2}$ makes the process a type of combination of the precipitation and adsorption, hence reducing the removal efficiency. The highest removal has been observed at a $\mathrm{pH}$ value of 6 . Figure 3 shows the solution $\mathrm{pH}$ effect for removing $\mathrm{Cu}(\mathrm{II})$ ions using rice husk.

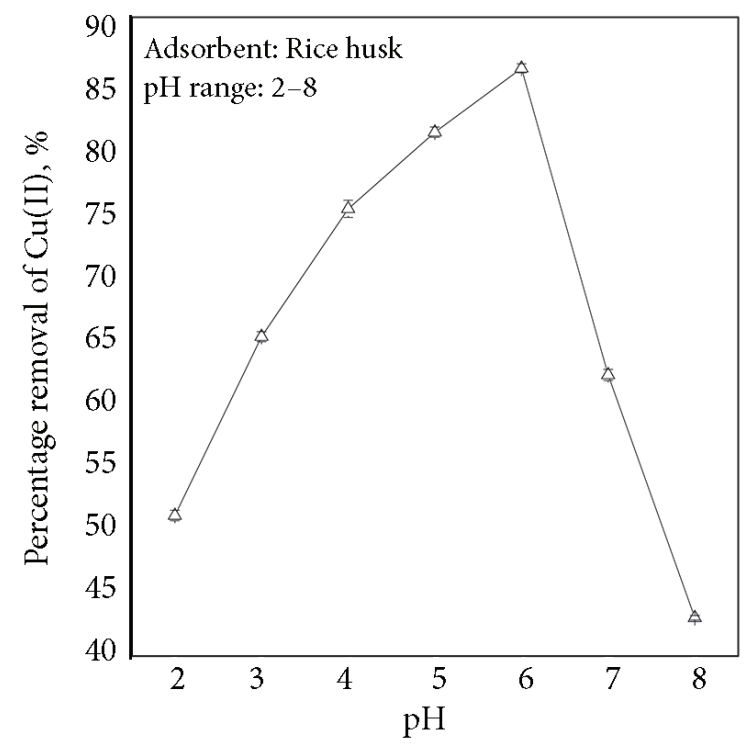

Figure 3. Effect of $\mathrm{pH}$

In this study, the experiment was done using different bed depths $(4 \mathrm{~cm}, 6 \mathrm{~cm}$, and $10 \mathrm{~cm})$ to determine the process's optimum condition. The highest bed depth $(10 \mathrm{~cm})$ was found as the optimum as higher removal was observed at bed depth $10 \mathrm{~cm}$. The higher bed depth provides the more free adsorption sites, making more metal ions to adsorb the blank sites and making the more significant adsorption of metal ions (Mitra \& Das, 2020). Figure 4 is the figure depicting the effect of bed depth on this study.

Figure 5 is the representative figure of the variation of the flow rate $(10 \mathrm{ml} / \mathrm{min}-40 \mathrm{ml} / \mathrm{min})$. It is observed that with the increasing flow rate, the breakthrough time decreases rapidly (Banerjee et al., 2019). The adsorbent surface gets less time to get in touch with metal ions to adsorb less and forms a sharp breakthrough curve at increasing flow rate. Hence, the lowest flow rate $\left(10 \mathrm{ml} . \mathrm{min}^{-1}\right)$ is useful for the process.

Figure 6 explains the variation of influent metal ion concentration at constant bed depth to the flow rate. It is shown from the figure that, at higher $\mathrm{Cu}(\mathrm{II})$ ion concentration, the breakthrough time becomes less (Kumar et al., 2019). More $\mathrm{Cu}(\mathrm{II})$ ions adsorb into the free adsorption sites at a higher concentration. The rice husk is getting saturated by adsorbing more metal ions in a short time and lost its capacity for further adsorption.

\subsection{Kinetic model}

\subsubsection{Thomas model (Thomas, 1948)}

Thomas model is used to study the breakthrough performance in the continuous process. The linearized model equation is as follow:

$$
\ln \left(\frac{C_{0}}{C_{t}}-1\right)=\frac{k_{t h} q_{0} x}{v}-k_{t h} C_{0} t
$$

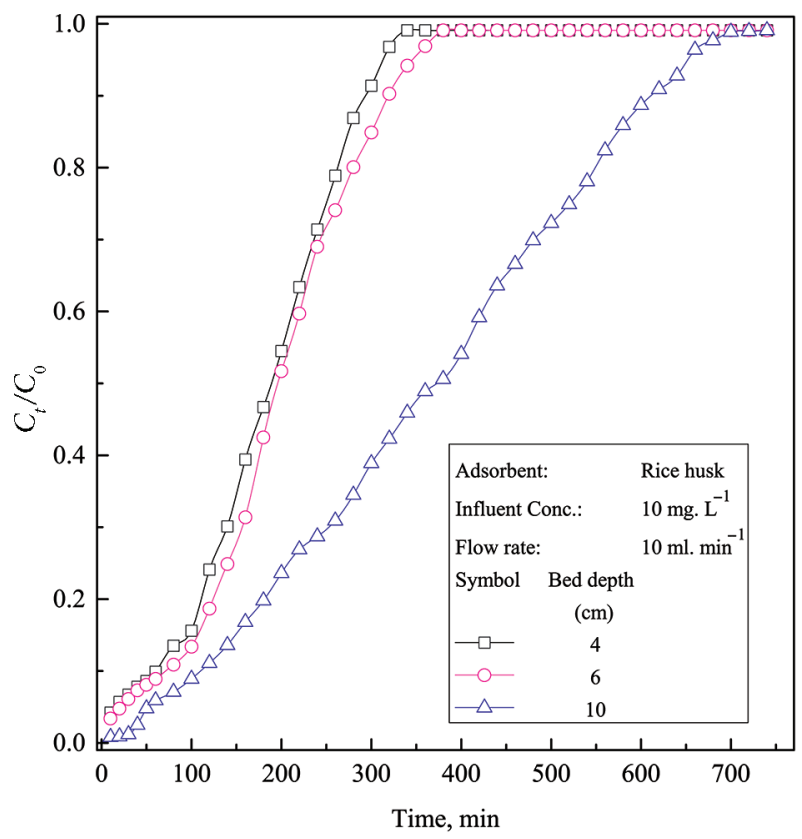

Figure 4. Effect of the bed depth

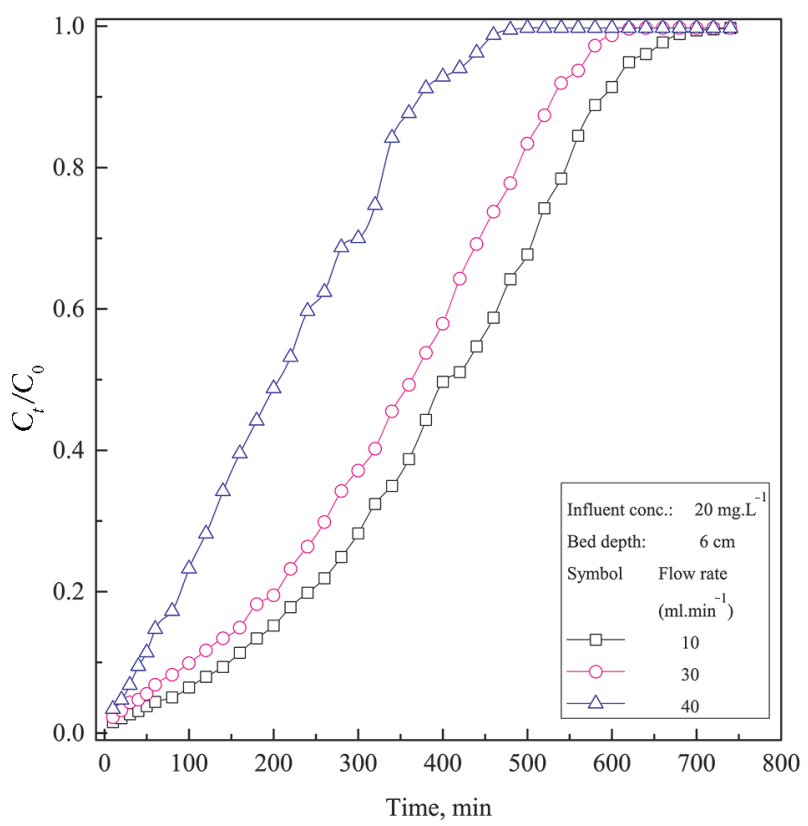

Figure 5. The effect of the flow rate 


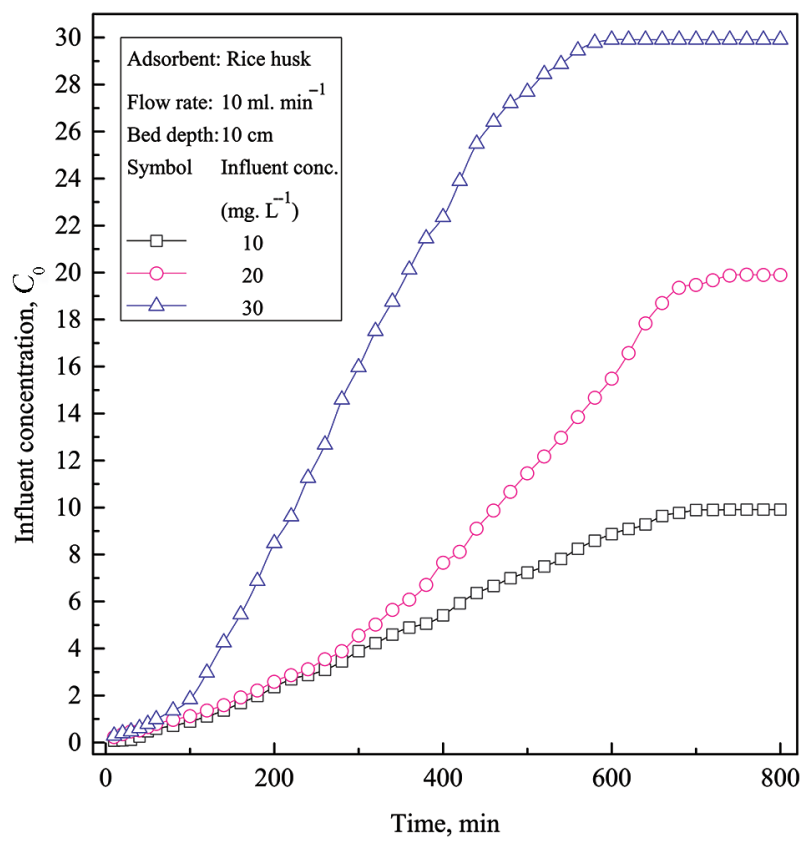

Figure 6. Effect of the influent concentration

Table 1. Thomas model parameters

\begin{tabular}{|c|c|c|c|}
\hline \multicolumn{4}{|c|}{$\begin{array}{l}\text { Variation of the bed depth } \\
\text { The flow rate is } 10 \mathrm{ml} / \mathrm{min} \text {, and the inlet conc. is } 10 \mathrm{mg} / \mathrm{L}\end{array}$} \\
\hline $\begin{array}{c}\text { Bed depth } \\
Z \\
(\mathrm{~cm})\end{array}$ & $\begin{array}{c}\text { The model } \\
\text { rate constant, } \\
k_{t h} \times 10^{3} \\
(\mathrm{~L} / \mathrm{mg} / \mathrm{min})\end{array}$ & $\begin{array}{c}\text { The } \\
\text { maximum } \\
\text { metal uptake } \\
\text { capacity, } q_{0} \\
\left(\mathrm{mg} . \mathrm{g}^{-1}\right)\end{array}$ & $\begin{array}{c}\text { Correlation } \\
\text { coefficient } \\
R^{2}\end{array}$ \\
\hline 4 & 1.63 & 5.09 & 0.9821 \\
\hline 6 & 1.54 & 4.24 & 0.9737 \\
\hline 10 & 1.64 & 3.86 & 0.8841 \\
\hline \multicolumn{4}{|c|}{$\begin{array}{l}\text { Variation of the rate of flow } \\
\text { The bed depth is } 4 \mathrm{~cm} \text { and the inlet conc. is } 20 \mathrm{mg} / \mathrm{L}\end{array}$} \\
\hline $\begin{array}{l}\text { Flow rate } v \\
(\mathrm{ml} / \mathrm{min})\end{array}$ & $\begin{array}{c}\text { The model } \\
\text { rate constant, } \\
k_{t h} \times 10^{3} \\
(\mathrm{~L} / \mathrm{mg} / \mathrm{min})\end{array}$ & $\begin{array}{l}\text { The } \\
\text { maximum } \\
\text { metal uptake } \\
\text { capacity, } q_{0} \\
(\mathrm{mg} / \mathrm{g})\end{array}$ & $\begin{array}{c}\text { Correlation } \\
\text { coefficient } \\
R^{2}\end{array}$ \\
\hline 10 & 0.64 & 7.70 & 0.9962 \\
\hline 30 & 0.84 & 5.58 & 0.9868 \\
\hline 40 & 1.77 & 2.61 & 0.9493 \\
\hline \multicolumn{4}{|c|}{$\begin{array}{l}\text { Variation of influent concentration } \\
\text { The rate of the flow is } 10 \mathrm{ml} / \mathrm{min} \text {, and the bed depth is } 4 \mathrm{~cm}\end{array}$} \\
\hline $\begin{array}{l}\text { Influent } \\
\text { conc., } C_{0} \\
(\mathrm{mg} / \mathrm{L})\end{array}$ & $\begin{array}{c}\text { The model } \\
\text { rate constant, } \\
k_{t h} \times 10^{3} \\
(\mathrm{~L} / \mathrm{mg} / \mathrm{min})\end{array}$ & $\begin{array}{l}\text { The } \\
\text { maximum } \\
\text { metal uptake } \\
\text { capacity, } q_{0} \\
(\mathrm{mg} / \mathrm{g})\end{array}$ & $\begin{array}{c}\text { Correlation } \\
\text { coefficient } \\
R^{2}\end{array}$ \\
\hline 10 & 1.63 & 5.09 & 0.9821 \\
\hline 20 & 0.64 & 7.70 & 0.9962 \\
\hline 30 & 0.99 & 10.93 & 0.9487 \\
\hline
\end{tabular}

The $k_{t h}$ and $q_{0}$ are obtained from $\ln \left(\frac{C_{0}}{C_{t}}-1\right)$ vs. $t$ plot. The representative value of model parameters with the value of $R^{2}$ is shown in Table 1 , and Figure 7 is the representative figure for the model plot. With the increase of flow rate and bed height, adsorption capacity $\left(q_{0}\right)$, decreases, whereas, with the rise of influent concentration, it increases. No trend of $k_{t h}$ on the operating variables is observed. The correlation coefficient, $R^{2}$ varies from 0.8841 to 0.9962 and indicates s statistically acceptable model. The maximum $\mathrm{Cu}(\mathrm{II})$ adsorption capacity is $10.93 \mathrm{mg} / \mathrm{g}$ at $z=4 \mathrm{~cm}, v=30 \mathrm{mg} / \mathrm{L}$, and $C_{0}=30 \mathrm{mg} / \mathrm{L}$.

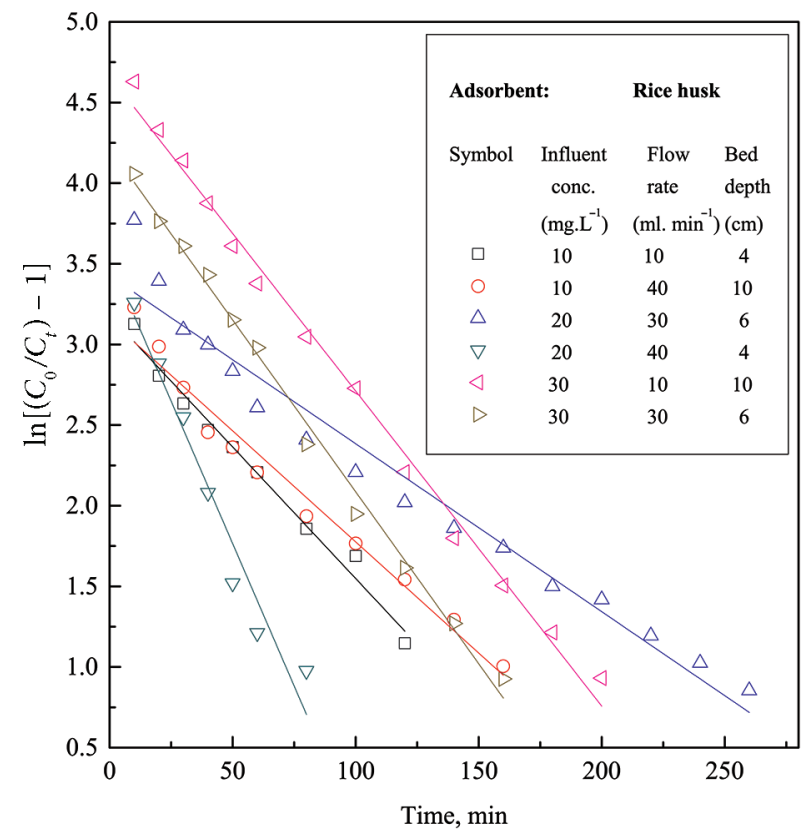

Figure 7. Thomas model graph

\subsubsection{Bohart-Admas model (Bohart \& Admas, 1920)}

The fixed-bed column performance is described by the Bohart-Admas model also. The linear form of equation is as below:

$$
\ln \left(\frac{C_{t}}{C_{0}}\right)=K_{A B} C_{0} t-K_{A B} N_{0}\left(\frac{z}{u_{0}}\right) .
$$

The $K_{A B}$ and $N_{0}$ are determined from linearized plotting of $\ln \left(\frac{C_{t}}{C_{0}}\right)$ and $t$. Table 2 present the model parameters along with $R^{2}$ value, and Figure 8 is the model plot for the $\mathrm{Cu}(\mathrm{II})$ ions removal using rice husk. The $K_{A B}$ value increases with the rise $v$ and decreases with $z$, but no trend is observed on the increase of influent concentration. The $N_{0}$ value decreases with $v$ and $z$. The $R^{2}$ value varies from 0.8413 to 0.9914 and indicates the acceptable model. 
Table 2. Bohart-Admas model parameters

\begin{tabular}{|c|c|c|c|}
\hline \multicolumn{4}{|c|}{$\begin{array}{l}\text { Variation of the bed depth } \\
\text { The flow rate is } 10 \mathrm{ml} / \mathrm{min} \text {, and the inlet conc. is } 10 \mathrm{mg} / \mathrm{L}\end{array}$} \\
\hline $\begin{array}{c}\text { Bed depth } \\
Z \\
(\mathrm{~cm})\end{array}$ & $\begin{array}{c}\text { The model } \\
\text { rate constant, } \\
K_{A B} \times 1000 \\
(\mathrm{~L} / \mathrm{mg})\end{array}$ & $\begin{array}{l}\text { Saturation } \\
\text { conc., } N_{0} \\
\quad(\mathrm{~g} / \mathrm{L})\end{array}$ & $\begin{array}{c}\text { Correlation } \\
\text { coefficient } \\
R^{2}\end{array}$ \\
\hline 4 & 1.42 & 28.01 & 0.9914 \\
\hline 6 & 1.35 & 20.30 & 0.9773 \\
\hline 10 & 1.24 & 16.65 & 0.8482 \\
\hline \multicolumn{4}{|c|}{$\begin{array}{l}\text { Variation of the rate of flow } \\
\text { The bed depth is } 4 \mathrm{~cm} \text { and the inlet conc. is } 20 \mathrm{mg} / \mathrm{L}\end{array}$} \\
\hline $\begin{array}{c}\text { Flow rate } \\
v \\
(\mathrm{ml} / \mathrm{min})\end{array}$ & $\begin{array}{c}\text { The model } \\
\text { rate constant, } \\
K_{A B} \times 1000 \\
(\mathrm{~L} / \mathrm{mg})\end{array}$ & $\begin{array}{l}\text { Saturation } \\
\text { conc., } N_{0} \\
\quad(\mathrm{~g} / \mathrm{L})\end{array}$ & $\begin{array}{c}\text { Correlation } \\
\text { coefficient } \\
R^{2}\end{array}$ \\
\hline 10 & 0.49 & 92.71 & 0.9740 \\
\hline 30 & 0.65 & 66.81 & 0.9696 \\
\hline 40 & 0.91 & 41.63 & 0.8413 \\
\hline \multicolumn{4}{|c|}{$\begin{array}{l}\text { Variation of the influent conc. } \\
\text { The rate of the flow is } 10 \mathrm{ml} / \mathrm{min} \text {, and the bed depth is } 4 \mathrm{~cm}\end{array}$} \\
\hline $\begin{array}{l}\text { Influent } \\
\text { conc., } C_{0} \\
(\mathrm{mg} / \mathrm{L})\end{array}$ & $\begin{array}{c}\text { The model } \\
\text { rate constant, } \\
K_{A B} \times 1000 \\
(\mathrm{~L} / \mathrm{mg})\end{array}$ & $\begin{array}{l}\text { Saturation } \\
\text { conc., } N_{0} \\
\quad(\mathrm{~g} / \mathrm{L})\end{array}$ & $\begin{array}{c}\text { Correlation } \\
\text { coefficient } \\
R^{2}\end{array}$ \\
\hline 10 & 1.42 & 28.01 & 0.9914 \\
\hline 20 & 0.49 & 92.71 & 0.9740 \\
\hline 30 & 0.70 & 68.04 & 0.9071 \\
\hline
\end{tabular}

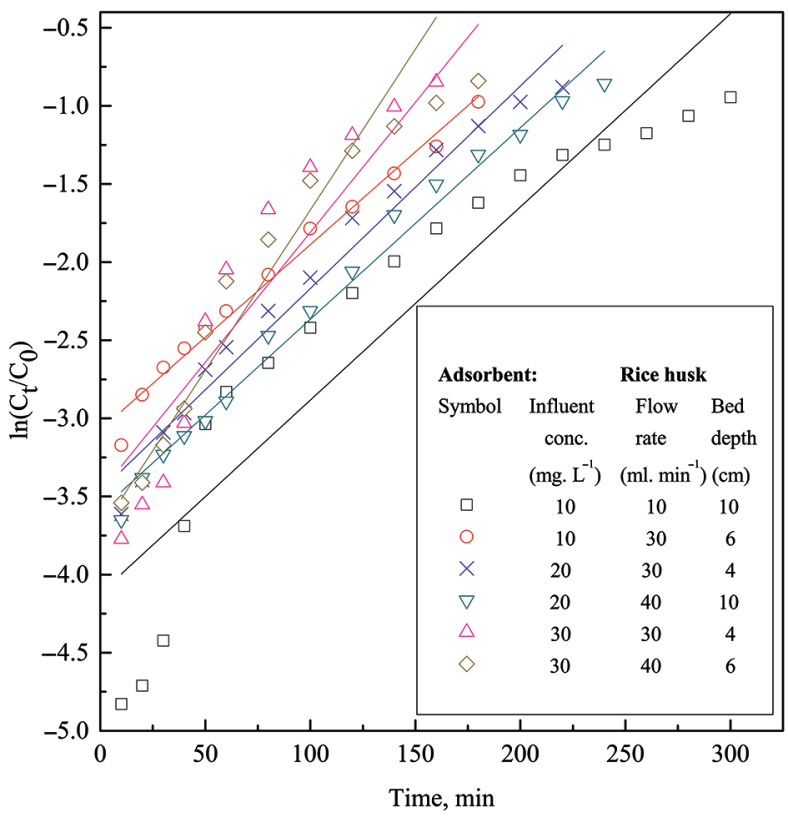

Figure 8. Bohart-Admas model graph

By comparing the two models mentioned above, we can conclude that the Thomas model is slightly better than the Bhart-Admas model.

\subsection{Treatment of the industrial effluent water}

Industrial effluent water has been collected from a smallsized electroplating industry close to the city of Kolkata. Adsorption of the industrial effluent is conducted after the $\mathrm{pH}$ has been adjustment to 6 and using a bed height of $4 \mathrm{~cm}$ with a $10 \mathrm{ml} / \mathrm{min}$ flow rate. The composition of the treated effluent is shown in Table 3 at the breakthrough point. It is observed that the performance of rice hush is suitable for $\mathrm{Cu}(\mathrm{II})$ containing wastewater.

Table 3. Composition of untreated and treated wastewater

\begin{tabular}{|c|c|c|}
\hline $\begin{array}{c}\text { Parameters } \\
(\mathrm{mg} / \mathrm{L})\end{array}$ & $\begin{array}{c}\text { Untreated } \\
\text { wastewater }\end{array}$ & $\begin{array}{c}\text { Treated wastewater } \\
\text { at breakthrough } \\
\text { point }\left(t_{b}\right)(\mathrm{mg} / \mathrm{L})\end{array}$ \\
\hline $\mathrm{pH}$ & 5.62 & 5.74 \\
\hline $\mathrm{Cu}(\mathrm{II})$ & 7.51 & 0.85 \\
\hline $\mathrm{Cr}(\mathrm{VI})$ & 43.60 & 34.80 \\
\hline $\mathrm{Ca}(\mathrm{II})$ & 25.25 & 24.10 \\
\hline $\mathrm{Na}(\mathrm{I})$ & 160.26 & 122.50 \\
\hline $\mathrm{K}(\mathrm{I})$ & 2.15 & 1.43 \\
\hline $\mathrm{Zn}(\mathrm{II})$ & 1.67 & 1.56 \\
\hline $\mathrm{TDS}$ & 815.0 & 676.00 \\
\hline
\end{tabular}

\subsection{MLR model}

For the study using regression to predict the percentage removal as dependent variable $(y)$, the independent variables for consideration are temperature $\left(x_{1}\right)$, bed depth $\left(x_{2}\right)$, flow rate $\left(x_{3}\right)$, influent concentration $\left(x_{4}\right)$, and effluent concentration $\left(x_{5}\right)$. The variables with their range have been shown in Table 4.

Table 4. Range of the variables

\begin{tabular}{|l|c|c|}
\hline \multicolumn{2}{|c|}{ Variables (independent) } & Range \\
\hline Time (min) & $x_{1}$ & Rice husk \\
\hline Flow rate $(\mathrm{ml} / \mathrm{min})$ & $x_{2}$ & 10 to 780 \\
\hline Bed depth $(\mathrm{cm})$ & $x_{3}$ & 4 to 10 \\
\hline Influent concentration $(\mathrm{mg} / \mathrm{L})$ & $x_{4}$ & 10 to 30 \\
\hline Effluent concentration $(\mathrm{mg} / \mathrm{L})$ & $x_{5}$ & 0.08 to 29.91 \\
\hline Variable (dependent) & $y$ & 0.25 to 99.20 \\
\hline The removal percentage & & 755 \\
\hline Number of data & \\
\hline
\end{tabular}

The equation for calculation of removing efficiency of the $\mathrm{Cu}(\mathrm{II})$ ions is:

$$
\begin{aligned}
& y=0.905666-0.664508 \times x_{1}-0.072669 \times x_{2}+ \\
& 0.082284 \times x_{3}+0.245618 \times x_{4}-0.769871 \times x_{5} .
\end{aligned}
$$

The variance, mean squared error, and the correlation coefficient obtained from Eq. (1) are 0.077854, 0.006061, and 0.961296 . Here, this $t$-value is 1.963 for 749 degrees of freedom, and the confidence range has been 95\%. Figure 9 shows the correlation plot. 


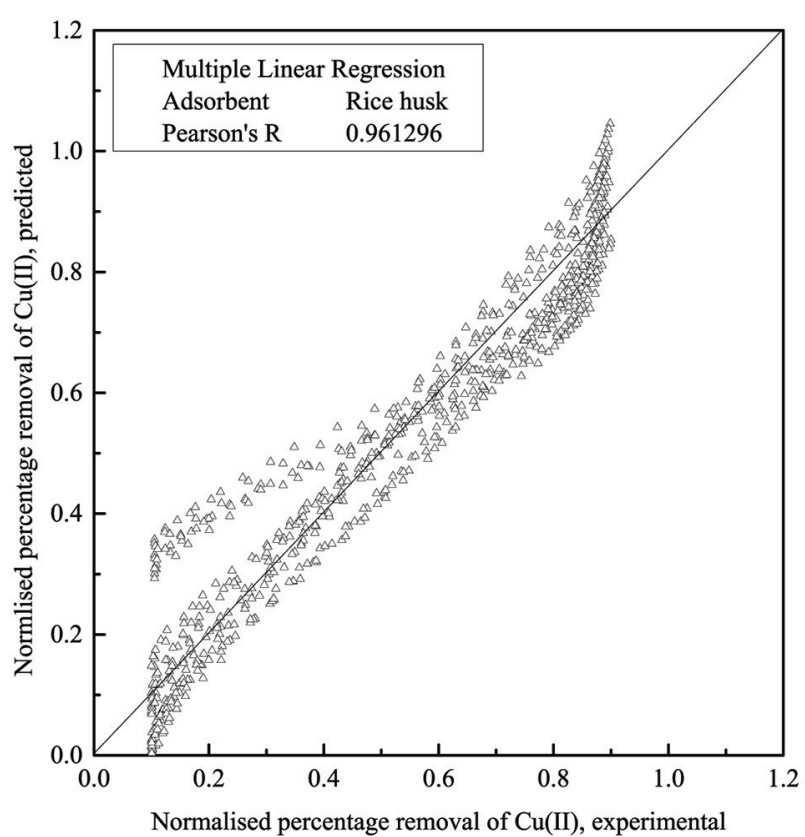

Figure 9. MLR plot for rice husk used as adsorbent

\subsection{Neural Network processing}

Initially, the data set is randomized 3 times and generate 3 independent data set for ANN analysis. The LevenbergMarquardt algorithm has been applied with a hidden layer along with a output layer. Hyperbolic tangent (tanh) (Bar et al., 2011; Singha et al., 2015; Nag et al., 2017; Maiti et al., 2019) transfer function is used in the hidden and output layer. The input parameters have been described in the Table $3.70 \%$ of the data used for training. The training process is a complex statistical or mathematical information that is applicable towards the task of updating the weights concerning all the different synapses that are connected with the nodes of the hidden layer and the input and output layers. The algorithm is responsible for making changes to the weights after the calculation of the overall error regarding the training during each epoch. For each epoch, these weight values are changed by a small amount that is randomly chosen either by subtraction or by addition with the preceding value of weights that are recorded as well as stored for each synapse. As a result of which if the corresponding error value has been found to be improved, then this process of addition and/or subtraction continues. Here, the stopping criteria presents us with an excellent solution for stopping this training at a moment when this error value reaches its optimised magnitude. From the Figure 10, it can be clearly observed from the green curve for $\mathrm{S}_{3}$.

The use of the optimised value has been achieved after calculating the corresponding cross-validation (MSE) during any particular moment when the weights have been changed or updated simultaneously during the training process. The choice of cross-validation MSE for the application of the stopping criterion has been a good practice due to the fact that it eliminates nearly all possibility of overtraining. Therefore, each sample's $20 \%$ data kept separately for cross-validation (Holdout method) plays a vital role. Here, the processing elements number is optimized with the evaluation of this cross-validation error. This optimum value of processing elements number is 25 , 25 , and 22 for the sample $S_{1}$, sample $S_{2}$ and sample $S_{3}$. This application can be visually observed in Figure 10. The cross-validation curve for sample number 2 is presented in Figure 10. The rest $10 \%$ of the data was used for the final prediction.

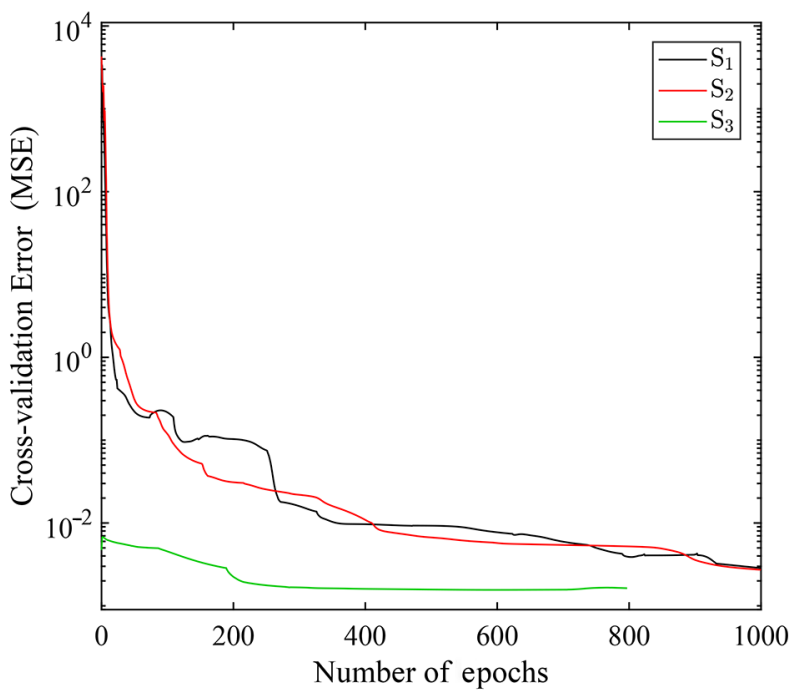

Figure 10. Cross-validation curves

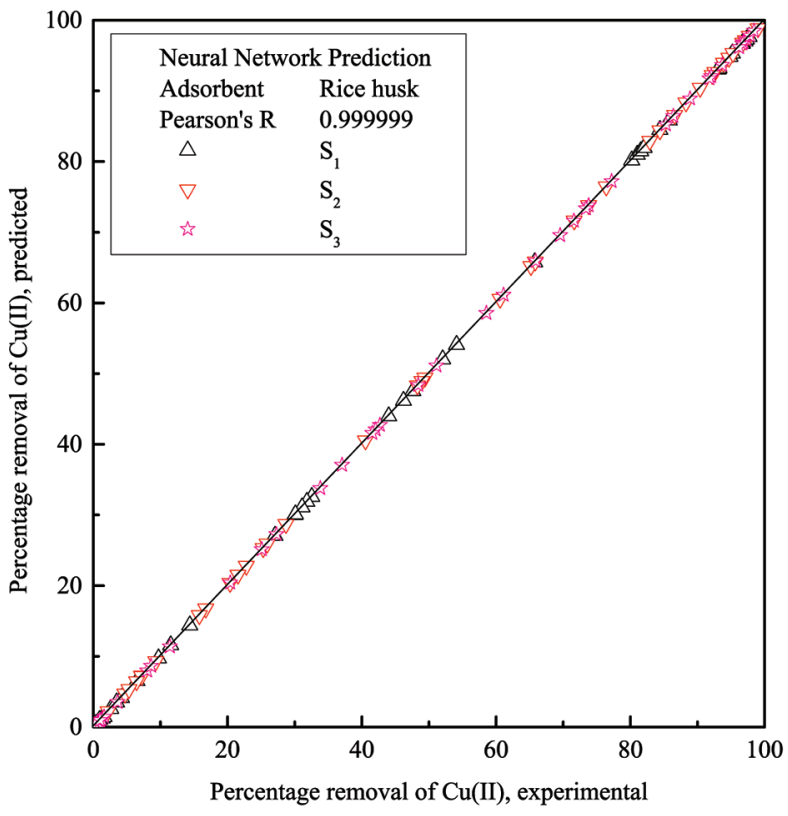

Figure 11. Neural network comparison plot

The result in Table 5 shows that the three samples' prediction is consistent with each other as each sample produces satisfactory results with reasonable accuracy, as suggested by R's final value for all three samples. This information alone provides the indication, that the whole 
Table 5. Results related to the prediction using LM algorithm

\begin{tabular}{|c|c|c|c|c|c|}
\hline $\begin{array}{c}\text { Sample } \\
\text { number }\end{array}$ & $\begin{array}{c}\text { Mini- } \\
\text { mum } \\
\text { cross- } \\
\text { vali- } \\
\text { dation } \\
\text { error }\end{array}$ & AARE & SD & MSE & $\mathrm{R}$ \\
\hline $\mathrm{S}_{1}$ & 0.002855 & 0.012310 & 0.034033 & 0.003310 & 0.999999 \\
\hline $\mathrm{S}_{2}$ & 0.002720 & 0.001051 & 0.002449 & 0.001496 & 0.999999 \\
\hline $\mathrm{S}_{3}$ & 0.001557 & 0.023013 & 0.078862 & 0.002832 & 0.999999 \\
\hline
\end{tabular}

modelling, i.e., the training, the cross-validation along with the network's final prediction has been exceptionally accurate. The observation of the Figure 11 further emphasises this fact. Figure 11 presents a comparison concerning the experimental and it's corresponding neural network prediction when Rice husk is used as bio adsorbent to evaluate $\mathrm{Cu}(\mathrm{II})$ removal efficiency from aqueous solution.

\section{Conclusions}

Rice husk is used to treat $\mathrm{Cu}(\mathrm{II})$ ions in fixed-bed column mode without any modification or treatment. Physical characterization was made to identify rice husk's physical properties, and the experiment was done to check the suitability of rice husk to remove $\mathrm{Cu}(\mathrm{II})$ ions. The maximum adsorption capacity obtained from the Thomas model is $10.93 \mathrm{mg} / \mathrm{g}$ at influent concentration $30 \mathrm{mg} / \mathrm{L}$, flow rate $10 \mathrm{ml} / \mathrm{min}$, along with the bed height of $4 \mathrm{~cm}$. Thomas and Bohart-Admas models are used for predicting the breakthrough curves. Thomas model predicts the breakthrough curve better than the other model. Experimental data was used to predict the Empirical/semi-empirical model. Artificial neural network prediction was performed with the experimental data to check the adsorption capacity (i.e., percentage removal) of rice husk and MLR. The ANN prediction was found to be better than the prediction using MLR.

\section{References}

Aydin, H., Bulut Y., \& Yerlikaya, Ç. (2008). Removal of copper (II) from aqueous solution by adsorption onto low-cost adsorbents. Journal of Environmental Management, 87(1), 3745. https://doi.org/10.1016/j.jenvman.2007.01.005

Banerjee, M., Basu, R. K., \& Das, S. K. (2019). Adsorptive removal of $\mathrm{Cu}$ (II) by pistachio shell: Isotherm study, kinetic modelling and scale-up designing - continuous mode. Environmental Technology \& Innovation, 15, 100419.

https://doi.org/10.1016/j.eti.2019.100419

Bar, N., Biswas, M. N., \& Das, S. K. (2011). Frictional pressure drop prediction using ANN for gas-non-Newtonian liquid flow through $45^{\circ}$ bend. Artificial Intelligent Systems and Machine Learning, 3(9), 608-613.

Bohart, G., \& Admas, E. N. (1920). Some aspects of the behavior of charcoal with respect to chlorine. Journal of American Chemical Society, 42(3), 523-544.

https://doi.org/10.1021/ja01448a018
Bureau of Indian standards. (1991). Drinking water specifications (IS 10500:1991). New Delhi.

Das, A., Bar N., \& Das, S. K. (2020). Pb(II) adsorption from aqueous solution by nutshells, green adsorbent: Adsorption studies, regeneration studies, scale-up design, its effect on biological indicator and MLR modelling. Journal of Colloid and Interface Science, 580, 245-255.

https://doi.org/10.1016/j.jcis.2020.07.017

Das, B., Ganguly, U. P., Bar, N., \& Das, S. K. (2015). Holdup prediction in inverse fluidization using non-Newtonian pseudoplastic liquids: Empirical correlation \& ANN modeling. Powder Technology, 273, 83-90.

https://doi.org/10.1016/j.powtec.2014.12.034

Environmental Protection Agency. (1990). Environmental Pollution Control Alternatives. EPA/625/5-90/025, EPA/625/489/023. Cincinaati OH USA.

Gayathri, U., Venkatraman, B. R., \& Arivoli, S. (2011). Removal of Copper(II) ions from aqueous solutions by adsorption with low cost acid activated Cynodon dactylon carbon. E-Journal of Chemistry, 8(S1), S377-S391. https://doi.org/10.1155/2011/435482

Kumar, G. V. S. R. P., Malla, K. A., Yerra, B., \& Rao, K. S. (2019). Removal of $\mathrm{Cu}$ (II) using three lowcost adsorbents and prediction of adsorption using artifcial neural networks. Applied Water Science, 9, 44. https://doi.org/10.1007/s13201-019-0924-x

Maiti, S. B., Bar, N., \& Das, S. K. (2019). Fluidization using pseudoplastic liquids - elutriation and ANN modeling. Advanced Powder Technology, 30(12), 2940-2946. https://doi.org/10.1016/j.apt.2019.09.001

Maiti, S. B., Let, S., Bar, N., \& Das, S. K. (2018). Non-spherical solid-non-Newtonian liquid fluidization and ANN modelling: Minimum fluidization velocity. Chemical Engineering Science, 176, 233-241. https://doi.org/10.1016/j.ces.2017.10.050

Mandal, A., Bar, N., \& Das, S. K. (2020). Phenol removal from wastewater using low-cost natural bioadsorbent neem (Azadirachta indica) leaves: Adsorption study and MLR modeling. Sustainable Chemistry \& Pharmacy, 17, 100308. https://doi.org/10.1016/j.scp.2020.100308

Mitra, T., \& Das, S. K. (2020). Removal of Cu(II) ions using bioadsorbents in fixed - bed continuous bed mode - A comparative study and scale-up design. Environmental Progress \& Sustainable Energy, 39(5), e013417. https://doi.org/10.1002/ep.13417

Mitra, T., Singha, B., Bar, N., \& Das, S. K. (2014). Removal of $\mathrm{Pb}$ (II) ions from aqueous solution using water hyacinth root by fixed-bed column \& ANN modeling. Journal of Hazardous Materials, 273, 94-103. https://doi.org/10.1016/j.jhazmat.2014.03.025

Nag, S., Bar, N., \& Das, S. K. (2020). Cr(VI) removal from aqueous solution using green adsorbents in continuous bed column - Statistical and GA-ANN hybrid modelling. Chemical Engineering Science, 226, 115904. https://doi.org/10.1016/j.ces.2020.115904

Nag, S., Mondal, A., Bar, N., \& Das, S. K. (2017). Bio-sorption of Chromium (VI) from aqueous solutions and ANN modeling. Environmental Science and Pollution Research, 24(23), 18817-18835. https://doi.org/10.1007/s11356-017-9325-6

Singha, B., \& Das, S. K. (2013). Adsorptive removal of $\mathrm{Cu}(\mathrm{II})$ from aqueous solution and industrial effluent using natural / natural wastes. Colloids and Surfaces B: Biointerfaces, 107, 97-106. https://doi.org/10.1016/j.colsurfb.2013.01.060

Singha, B., Bar, N., \& Das, S. K. (2015). The use of artificial neural network (ANN) for modeling of $\mathrm{Pb}(\mathrm{II})$ adsorption 
in batch process. Journal of Molecular Liquids, 211, 228-232. https://doi.org/10.1016/j.molliq.2015.07.002

Thomas, H. G. (1948). Chromatography: A problem in kinetics. Annals of the New York Academy of Sciences, 49(2), 161-182. https://doi.org/10.1111/j.1749-6632.1948.tb35248.x

Tumin, N. D., Chuah, A. L., Zawani, Z., \& Rashid, S. A. (2008). Adsorption of copper from aqueous solution by Elais guineensis kernel activated carbon. Journal of Engineering Science and Technology, 3(2), 180-189.

World Health Organization. (1993). Guidelines for drinking water quality: Vol. 1. Recommendations ( $2^{\text {nd }}$ ed.). Geneva.

\section{APPENDIX}

\section{Nomenclature}

$C_{0}$ the influent metal ion conc. when $t$ is equal to 0 $(\mathrm{mg} / \mathrm{L})$.

$C_{t} \quad$ the effluent metal ion conc. in $\mathrm{mg} / \mathrm{L}$ when the time is $t$.

$C_{t} / C_{0}$ the relative conc.

$N_{0} \quad$ Saturation conc. (mg/L).

$q_{0} \quad$ Maximum value of metal uptake for each gram of adsorbent $(\mathrm{mg} / \mathrm{g})$.

$t \quad$ Contact time (min).

$u_{0} \quad$ Superficial velocity $(\mathrm{m} / \mathrm{min})$. 